\title{
Święty Jan Paweł II o duchowości laikatu
}

Przez wiele wieków historii Kościoła ludzi świeckich definiowano w sposób negatywny, podkreślając, że nie są duchownymi. Prawdziwym przełomem w tej dziedzinie był Sobór Watykański II ${ }^{2}$. Po raz pierwszy dokumenty Kościoła dostarczyły pozytywnego, ,typologicznego” opisu człowieka świeckiego ${ }^{3}$. Konstytucja dogmatyczna o Kościele Lumen gentium (31) stwierdziła, że świeccy to ochrzczeni, uczestniczący w sposób sobie właściwy w kapłańskim, prorockim i królewskim urzędzie Chrystusa i stosownie do swoich możliwości realizujący posłannictwo w Kościele i świecie. Swoistą „różnicą gatunkową" świeckich w stosunku do innych ochrzczonych jest ich „charakter świecki" (indoles saecularis), polegający na tym, że z tytułu Bożego powołania pozostają w świecie i uświęcają go od wewnątrz ${ }^{4}$. Dekret o apo-

1 Ks. prof. dr hab. Wojciech Zyzak, ur. 17 czerwca 1969 w Żywcu, kapłan diecezji bielsko-żywieckiej, święcenia 15 maja 1993, doktorat KUL 2000, habilitacja PAT 2006, profesura tytularna UPJP2 2013. Dziekan Wydziału Teologicznego Uniwersytetu Papieskiego Jana Pawła II w Krakowie. Od 2014 rektor Uniwersytetu Jana Pawła II w Krakowie. Autor 9 książek i ponad 80 artykułów. Ostatnie publikacje książkowe: Co mam czynić, aby osiagnać życie wieczne? Duchowość chrześcijańska na świeckiej drodze życia, Kraków 2007; Kapłaństwo prezbiterów. Studium nauczania Jana Pawła II, Kraków 2010.

2 Por. Y. Congar, Laïc et laïcat, [w:] Dictionnaire de spiritualité, ed. M. Viller, t. 9, Paris 1976, k. 102 n.

3 Por. E. Schillebeeckx, La définition typologique du laic chrétien selon Vatican II, [w:] L'Église de Vatican II. Commentaires, t. III, Paris 1966, s. 120.

4 Por. E. Weron, Teologia życia wewnętrznego ludzi świeckich, Poznań-Warszawa 1980, s. 13n. 
stolstwie świeckich Apostolicam actuositatem (4) tegoż soboru w duchu powyższej definicji zarysował podstawy duchowości laikatu.

Po Soborze Watykańskim II wiele nowych impulsów w rozwoju teologii laikatu przyniósł zwłaszcza pontyfikat św. Jana Pawła II. Na szczególną uwagę zasługuje pod tym względem adhortacja Christifideles laici, będąca owocem synodu biskupów z 1987 roku. Ale już Lineamenta tegoż synodu zaleciły dalsze rozwijanie duchowości laikatu ${ }^{5}$. Duchowość ta, jak każda prawdziwa duchowość chrześcijańska, musi być oparta na rzetelnej teologii laikatu. Dlatego w poniższym tekście zostaną zaznaczone istotne elementy posoborowej duchowości ludzi świeckich, głównie w oparciu o najważniejsze tezy eklezjologiczne, przy czym celem artykułu jest uchwycenie inspiracji płynących z nauczania św. Jana Pawła II.

\section{Kontynuacja Soboru Watykańskiego II, Lumen gentium}

Święty Jan Paweł II w swym nauczaniu o laikacie jest przede wszystkim kontynuatorem wizji Soboru Watykańskiego II. Soborowa teologia laikatu odzwierciedla przejście od koncepcji Kościoła nadmiernie skoncentrowanego na hierarchii do eklezjologii, która odkrywa na nowo pojęcie Ludu Bożego. Pokazuje to układ rozdziałów Lumen gentium, gdzie hierarchiczny ustrój Kościoła (rozdział III) jest omawiany po ukazaniu Ludu Bożego (rozdział II), a nie przed, jak to było w pierwotnym projekcie. Podobnie przed rozdziałem o zakonnikach (rozdział VI) jest przedstawione powszechne powołanie do świętości (rozdział V) ${ }^{6}$. Ten sam układ zachował promulgowany przez Jana Pawła II w 1983 roku Kodeks prawa kanonicznego. W piramidalnej wizji Kościoła, która odcisnęła swoje piętno na poprzednim kodeksie, z 1917 roku, świeckim dawano niewiele miejsca na prawa. Jedyny kanon dotyczący wyłącznie świeckich (kanon 683) zabraniał im noszenia stroju duchownego. Inne, mówiące o świeckich, dotyczyły właściwie wszystkich wiernych. Nowy kodeks wyraził w języku prawnym teologiczną naukę Soboru, zwłasz-

\footnotetext{
Por. J. Dupuis, Lay people in Church and world. The contribution of recent literature to a synodal theme, „Gregorianum” 68 (1987) 1-2, s. 387.

Por. C. García, Espiritualidad de los laicos, Burgos 2004, s. 44n.
} 
cza konstytucji Lumen gentium 7 . Tam gdzie dawny kodeks mówił indywidualistycznie o osobach, obecny mówi o Ludzie Bożym. Nie stawia świeckich na końcu, za hierarchią i zakonnikami, ale najpierw rozpatruje wszystkich wiernych jako całość (kanony 208-223), a następnie świeckich (kanony 224231), by ostatecznie przejść do duchownych (kanony 232-293). To samo dotyczy układu trzech części drugiej księgi, z których pierwsza dotyczy wiernych, druga hierarchicznego ustroju Kościoła, a trzecia instytutów życia konsekrowanego i stowarzyszeń życia apostolskiego ${ }^{8}$. Wreszcie tym samym, soborowym śladem pójdzie synod biskupów z 1987 roku. Dokumenty przygotowujące mówiły po prostu o świeckich (laici), lecz ojcowie synodalni zdecydowali się na określenie „wierni świeccy” (christifideles laici), by nawiązać do drugiego rozdziału Lumen gentium i drugiej księgi Kodeksu prawa kanonicznego, gdzie jest najpierw mowa o wszystkich wiernych, a następnie o poszczególnych stanach? .

Na podkreślenie zasługuje fakt, że adhortacja Jana Pawła II Christifideles laici jest bardzo mocno zakorzeniona w nauczaniu Soboru i odwołuje się do jego dokumentów aż 97 razy nie tylko ze względu na stałą aktualność jego nauczania, ale także zapewne z powodu braku dostatecznej asymilacji jego nauki przez świeckich ${ }^{10}$. Adhortacja mówi o pełnym uczestnictwie świeckich w Kościele i jego misterium (8), o rzeczywistym byciu Kościołem (9), o uczestnictwie w kapłaństwie Chrystusa (14), o wadze chrztu i nowości chrześcijaństwa (10), o uczestnictwie w funkcji kapłańskiej, prorockiej i królewskiej Chrystusa (14), o wymiarze świeckim całego Kościoła (15), o wadze posług i nowych charyzmatów (21), o specyficznym i własnym charakterze świeckim laikatu (15). Dokument rozwija duchowość laikatu z podwójnej perspektywy Kościoła-komunii i Kościoła-misji ${ }^{11}$. Są to elementy już zaznaczone w dokumentach soborowych, zwłaszcza we wspomnianej opisowej definicji laikatu w Lumen gentium 31.

7 Por. A. Jacobs, Les laïcs, membres du peuple de Dieu, à travers le Code de droit canonique, „Revue Théologique de Louvain” (1987) 1, s. 30-32.

$8 \quad$ Por. A. Jacobs, Les laïcs, membres du peuple de Dieu..., dz. cyt., s. 33-40.

$9 \quad$ Por. G. Thils, Les laïcs et l'enjeu des temps „post-modernes”, Louvain-la-Neuve 1988, s. 7n.

10 Por. J. Schotte, „Christifideles laici” - prezentacja dokumentu, „Ateneum Kapłańskie” 114 (1990) z. 3, s. 361.

11 Por. C. García, Espiritualidad..., dz. cyt., s. 46n. 
Soborowe nauczanie zawarte jest też w innych dokumentach Jana Pawła II dotyczących wiernych świeckich. Na szczególną uwagę zasługują encykliki i adhortacje, zwłaszcza Laborem exercens, Catechesi tradendae i Familiaris consortio ${ }^{12}$. Trzeba też wspomnieć o nowym Katechizmie Kościoła katolickiego z 1992 roku (897-913) ${ }^{13}$. Duże znaczenie mają też różne wystąpienia, homilie i katechezy, zwłaszcza środowe, na temat laikatu, wygłaszane w 1993 i $1994 \mathrm{roku}^{14}$. Nie można też zapomnieć o dokumentach różnych dykasterii Stolicy Apostolskiej, jak choćby o Instrukcji o niektórych kwestiach dotyczących współpracy wiernych świeckich w ministerialnej posłudze kapłanów z 1997 roku ${ }^{15}$.

Przede wszystkim jednak trzeba podkreślić, że św. Jan Paweł II pogłębiał główne idee soborowe. Można przyjąć, że odnowa soborowa, krążąc wokół trzech biegunów, czyli powrotu do źródeł, powszechnego powołania do świętości i otwarcia na świat, położyła fundament pod współczesne ujęcie duchowości ludzi świeckich. W ramach charakterystycznej dla teologii soborowej eklezjologii ad intra i ad extra można ukazać człowieka świeckiego w podwójnej relacji. W tym ujęciu świecki jest postrzegany w wymiarze Kościoła-wspólnoty, która jest komunią z Bogiem i braćmi. Jest też ujmowany w wymiarze Kościoła-misji i powołany do wcielania w rzeczywistość doczesną wymagań Ewangelii ${ }^{16}$. Zdaniem Ciro Garcíi nowością soborową jest jeszcze głębsze ukazanie powołania wiernych świeckich do świętości oraz podkreślenie ich istotnego znaczenia wewnątrz Kościoła i ich zadania przemiany świata, również w aspekcie apostolstwa i misji. Tak więc prawdziwy świecki w wymiarze transcendencji otwiera się na Boga i rozwija tę otwartość w formie kontemplacji i poszukiwania misterium, w wymiarze komunii braterskiej otwiera się na spotkanie z innymi wiernymi, przyjmując życie Kościoła i rozwijając je jako przestrzeń wolnego spotkania z ludźmi, a w wy-

12 Por. R. Goldie, Świeccy, laikat, świeckość, tłum. S. Wawrzkowicz, Warszawa-Poznań 1991, s. 23n.

13 Por. E. Weron, Laikat w nowym katechizmie Kościoła, „Collectanea Theologica” 65 (1995) nr 4, s. 135.

14 Por. Jan Paweł II, Świeccy we wspólnocie chrześcijańskiej, red. E. Weron, Poznań 1997.

15 Por. P. Hünermann, Zum kirchenpolitischen Hintergrund und zur Bedeutung der Instruktion, [w:] Und dennoch... Die römische Instruktion über die Mitarbeit der Laien am Dienst der Priester. KlarstellungenKritik-Ermutigungen, hg. P. Hünermann, Freiburg 1998, s. 9.

16 Por. C. García, Espiritualidad..., dz. cyt., s. 7. 
miarze misji czuje się posłany do wyrażania przed innymi przesłania i rzeczywistości miłości, którą sam otrzymał. Te trzy wymiary dostrzegamy też w adhortacji Christifideles laici, która mówi w pierwszym rozdziale o godności świeckich w Kościele-Misterium, w drugim o uczestnictwie świeckich w życiu Kościoła-Komunii, a w trzecim o współodpowiedzialności świeckich w Kościele-Misji. Także pozostałe dwie adhortacje św. Jana Pawła II, skierowane do poszczególnych stanów życia w Kościele, a więc Pastores dabo vobis z 1992 i Vita consecrata z 1996 roku zachowują ten potrójny podział relacji do misterium, komunii i misji17. Szczególną zasługą Jana Pawła II wydaje się położenie akcentu na komunijny wymiar Kościoła.

\section{Komunijny wymiar Kościoła}

Już dokumenty soboru, a w ślad za nimi nowy kodeks uwypukliły zasadę fundamentalnej równości wszystkich ochrzczonych, kładąc nacisk na eklezjologiczne pojęcia Ludu Bożego i komunii ${ }^{18}$. Teologowie są zgodni, że szczególne znaczenie ma adhortacja apostolska Jana Pawła II Christifideles laici, która podkreśliła komunijno-wspólnotowy charakter wiernych świeckich $^{19}$. Bowiem od synodu, którego owocem jest adhortacja, zaznacza się prymat słowa „komunia”, które - choć w pewien sposób wyparło „Lud Boży”, charakterystyczny dla konstytucji Lumen gentium - zintegrowało jej główne aspekty eklezjologiczne, asymilując również fundamentalną koncepcję Kościoła jako sakramentu. Św. Jan Paweł II w liście apostolskim Novo millennio ineunte z 2001 roku wezwał do czynienia z Kościoła domu i szkoły komunii (43). Jego zdaniem potrzeba zarówno promocji duchowości komunii jako zasady edukacyjnej, jak i przypominania o Piotrowej posłudze komunii (44). Ważna jest komunia wewnętrzna i zewnętrzna, gdyż duchowość komunii ma być duszą struktury instytucjonalnej ${ }^{20}$.

17 Por. C. García, Espiritualidad..., dz. cyt., s. 119n.

18 Por. A. Antón, Principios Fundamentales para una teología del Laicado en la Eclesiología del Vaticano II, „Gregorianum” 68 (1987) 1-2, s. 129.

19 Por. C. García, Espiritualidad..., dz. cyt., s. 43; S. Nagy, Świeccy w komunijnej wspólnocie Kościoła, „Ateneum Kapłańskie” 114 (1990) z. 3, s. 379.

20 Por. C. García, Espiritualidad..., dz. cyt., s. 92-95. 
Duchowy wymiar komunii zaznacza się szczególnie w więzi pomiędzy poszczególnymi stanami życia w Kościele. Już sobór ukazał różne formy życia chrześcijańskiego i misji, kierując do duchownych Presbyterorum ordinis (1 i 9), do świeckich Lumen gentium (32) i Apostolicam actuositatem (2 i 3), a do zakonników Perfectae caritatis (1 i 8). Nauczanie soborowe znalazło swoiste dopełnienie w adhortacjach Pastores dabo vobis, Christifideles laici i Vita consecrata. Kategoria komunii w centrum definicji Kościoła oznacza przezwyciężenie eklezjologii piramidalnej czy klerykalnej. Właśnie w komunii należy widzieć prawdziwy model relacji duchownych, zakonników i świeckich. Problem tożsamości w nowej sytuacji religijnej wyraża się w terminach relacji. Zasadne więc wydaje się przejście od schematycznych opozycji duchowni-świeccy czy zakonnicy-świeccy do jednoczącej wizji Kościoła jako komunii. Taka integracja między różnymi formami życia chrześcijańskiego i powołanie do dzielenia charyzmatów nie jest przeszkodą w realizacji własnej tożsamości, ale wymaganiem istnienia w relacji, czyli bycia dla innych ${ }^{21}$. Gustave Thils przypomniał, że synod z 1987 roku z naciskiem mówi o parach „wierny duchowny” i „wierny świecki”. Bycie wiernym oznacza dla duchownych i świeckich wspólną kondycję chrześcijańską, życie z wiary, bycie ochrzczonym, pozostawanie w komunii z Bogiem, wcielenie w Ciało Chrystusa i postawę ucznia Jezusa. Z tego wypływa wspólna godność i wspólne działanie. Ta wspólna rzeczywistość jest bardziej fundamentalna niż rzeczywistość zadań lub posług kościelnych. Ona jest komunią życia z Trójcą Świętą, a posługi są służbą we wspólnocie. Ona wpisuje się w porządek celu, którym jest dążenie do świętości, a zadania należą do porządku środków, podejmowanych ze względu na uświęcenie i budowanie Kościoła. To tworzy realne braterstwo, które jest przed wszelkimi formami ojcostwa i przed honorowymi tytułami ${ }^{22}$. Konsekwencją tej komunii winno być dzielenie się duchowymi darami charakterystycznymi dla każdego stanu życia w Kościele.

Szczególnym wyrazem komunijnego charakteru Kościoła jest rodzina jako komunia osób. W Katechizmie Kościoła katolickiego czytamy, że „objawienie i właściwe urzeczywistnienie wspólnoty kościelnej ma miejsce

${ }^{21}$ Por. C. García, Espiritualidad..., dz. cyt., s. 71-73.

22 Por. G. Thils, Les laïcs et l'enjeu..., dz. cyt., s. 87-89. 
w rodzinie chrześcijańskiej, która również z tego powodu może i powinna nazywać się Kościołem domowym"23. Św. Jan Paweł II uczynił bardzo wiele, by promować komunijne przeżywanie rzeczywistości małżeństwa i rodziny. Już Sobór Watykański II podkreślił charakter wspólnotowy rodziny i nazwał ją Kościołem domowym ${ }^{24}$. Tę naukę rozwinął Jan Paweł II, szczególnie w adhortacji apostolskiej Familiaris consortio (1981). Dla papieża rodzina stanowi communio personarum, czyli cum-unio, jedność we wspólnocie, na wzór jedności Osób w Trójcy Świętej ${ }^{25}$.W ramy duchowości komunii wpisuje się prawdziwa teologia ciała rozwinięta przez świętego papieża, w której wcielenie i odkupienie są na równi źródłem sakramentalności małżeństwa ${ }^{26}$. Świadczą o tym szczególnie konferencje podczas środowych audiencji z przełomu 1979 i 1980 roku, w których ojciec święty ukazał, głównie w oparciu o pierwsze rozdziały Księgi Rodzaju, pierwotny zamysł Boga względem człowieka ${ }^{27}$.

Docenienie życia małżeńskiego znalazło swój symboliczny wymiar w pierwszej w historii wspólnej beatyfikacji pary małżeńskiej Ludwika i Marii Beltrame Quattrocchich, która odbyła się 21 października 2001 roku. W homilii Jan Paweł II przypomniał o powszechnym powołaniu do świętości, które w wypadku małżonków realizuje się na ich własnej drodze (propriam viam sequentes) (KK 41) ${ }^{28}$. „W życiu pary małżeńskiej i rodziny można zatem wyróżnić dwa podstawowe aspekty: uświęcenie we wspólnocie wiernej miłości i uświęcenie przez płodność, z którą wiąże się zadanie chrześcijańskiego wychowania potomstwa"29. Jan Paweł II w adhortacji Familiaris consortio

23 Katechizm Kościoła katolickiego, Poznań 1994, nr 2204; por. Jan Paweł II, adhort. apost. Familiaris consortio, 21.

24 Sobór Watykański II, konst. Lumen gentium [dalej: KK], 11.

25 Por. E. Weron, Apostolstwo małżonków i rodziny w nauczaniu Jana Pawła II, „Collectanea Theologica” 77 (2007) 1, s. 148n; T. Reroń, Rodzina, [w:] Leksykon duchowości katolickiej, red. M. Chmielewski, Lublin 2002, s. 754.

26 Por. A. Lizotte, La relation homme - famme comme signe del'Amour divin, „Carmel” 12 (2001) 102, s. 17-19.

27 Por. J. Warzecha, Papieska teologia matżeństwa, „Collectanea Theologica” 51 (1981) z. 3, s. 131 .

${ }_{28}$ Por. Homélie du pape Jean-Paul II pour la béatification de Luigi et Maria Beltrame Quattrocchi, „Carmel” 12 (2001) 102, s. 57.

${ }_{29}$ Jan Paweł II, Apostolstwo małżonków i rodziców, katecheza środowa z 3.08.1994, [w:] Jan Paweł II. Świeccy we wspólnocie chrześcijańskiej, red. E. Weron, Poznań 1997, s. 108. 
przypomniał, że „rodzina, założona i ożywiana przez miłość, jest wspólnotą osób: mężczyzny i kobiety jako małżonków, rodziców, dzieci i krewnych. Pierwszym jej zadaniem jest wierne przeżywanie rzeczywistości komunii w ciągłym działaniu na rzecz rozwijania prawdziwej wspólnoty osób”30. Takiemu rozumieniu znaczenia płci służy List do biskupów Kościoła katolickiego o współdziałaniu mężczyzny i kobiety w Kościele i świecie opublikowany przez Kongregację Nauki Wiary w 2004 roku. List ten wskazuje na błędne ujęcia feminizmu, który w formie liberalnej pragnie zatrzeć różnicę między mężczyzną a kobietą, a w formie radykalnej promuje kobiecy sposób postrzegania rzeczywistości jako lepszy ${ }^{31}$. Jan Paweł II bronił prawdziwej godności kobiety, o czym świadczy szczególnie list apostolski Mulieris dignitatem ${ }^{32}$. Również w tym aspekcie komunii różnorodność stanowi warunek duchowego ubogacania się. Ta różnorodność darów ma zdaniem świętego papieża prowadzić do wzajemnego uzupełniania się. Tak więc „kobieta ma «pomagać» mężczyźnie - a zarazem on ma jej pomagać - przede wszystkim w samym «byciu człowiekiem»" ${ }^{33}$.

Jan Paweł II przypominał, że

miłość małżonków, która nie zamyka się w samej sobie, ale zgodnie z nakazem prawa naturalnego otwiera się na nowe życie, z pomocą łaski Bożej staje się praktyką miłości świętej i uświęcającej, poprzez którą małżonkowie wspomagają wzrost Kościoła. To samo dotyczy obowiązku wychowania potomstwa, a więc zadania związanego z samą prokreacją ${ }^{34}$.

Jak komentuje papieskie nauczanie Walerian Słomka, trynitarna tajemnica życia Boga stanowi prawzór wspólnoty miłości. Owo Boskie „My” jest przedwiecznym prawzorem dla ludzkiego „my”, przede wszystkim dla tego, które mają stanowić mężczyzna i kobieta stworzeni na obraz i podobieństwo Boga. Osobowy charakter bytu ludzkiego oraz komunijny i komplementar-

30 Jan Paweł II, adhort. apost. Familiaris consortio, 18.

31 Por. A. Bławat, Watykański dokument o współdziałaniu mężczyzny i kobiety, „Collectanea Theologica" 76 (2006) 2, s. 189.

32 Jan Paweł II, list apost. Mulieris dignitatem, 1, 6.

33 Jan Paweł II, list apost. Mulieris dignitatem, 7.

${ }_{34}$ Jan Paweł II, Apostolstwo małżonków i rodziców, katecheza środowa z 3.08.1994, dz. cyt., s. 110 . 
ny charakter bytowania małżeńskiego wskazują również na prawdę o rodzicielstwie i rodzinie ${ }^{35}$. Jan Paweł II wyraża to w sposób następujący: „Tak jak dobro wspólne małżeństwa urzeczywistnia się poprzez miłość oblubieńczą, która gotowa jest dawać i przyjmować nowe życie - tak dobro wspólne rodziny urzeczywistnia się przez tę samą oblubieńczą miłość spełnioną w nowo narodzonym"36.

\section{Udział w potrójnym munus Chrystusa}

Sobór Watykański II w swej eklezjologii communio ukazał jedność i wielorakość charyzmatów, urzędów i posług. Podkreślił, że świeccy mają aktywny udział w trzech podstawowych posługach Kościoła (KK 34-36; DA 3), mianowicie przez nadprzyrodzony zmysł wiary i świadectwo w martyrii (KK 12), przez czynny udział (actuosa participatio) w liturgii ${ }^{37}$ i w królewskim urzędzie Chrystusa (diakonii), czyli służbie ludziom³.

Święty Jan Paweł II począwszy od swej pierwszej encykliki Redemptor hominis z 1979 roku podkreślał odpowiedzialność świeckich za losy Kościoła przez udział w prorockim posłannictwie Chrystusa (19). W 1981 roku w adhortacji Familiaris consortio przypomniał prawdę o uczestnictwie rodziny chrześcijańskiej w potrójnej misji Kościoła (50-64) ${ }^{39}$. Wreszcie w adhortacji Christifideles laici stwierdził: „Udział świeckich w potrójnym urzędzie Chrystusa, właśnie dlatego, że wywodzi się z przynależności do kościelnej wspólnoty, winien być przeżywany i realizowany we wspólnocie i dla wspólnoty"40. Dla świętego papieża szczególnie rodzina stanowi wspólnotę realizacji potrójnego urzędu Chrystusa. Rodzina wypełnia funkcję pro-

35 Por. W. Słomka, Cywilizacja miłości według Jana Pawła II „Listu do Rodzin”, „Roczniki Teologiczne" 5 (1995) 42, s. 30.

36 Jan Paweł II, List do rodzin, 2 lutego 1994 roku, 11.

37 Sobór Watykański II, konst. Sacrosanctum concilium [dalej: KL], 14, 30, 48, 50, 114.

38 Por. W. Kasper, Berufung und Sendung des Laien in Kirche und Welt. Geschichtliche und systematische Perspektiven, „Stimmen der Zeit” (1987) 205, s. 585.

39 Por. E. Weron, Budzenie olbrzyma, Poznań 1995, s. 177. Ludzie świeccy stanowili szczególny przedmiot zainteresowania ojca świętego już w czasach jego biskupiej posługi w Krakowie. Por. Z. Książek, Świeccy w postudze biskupiej kardynała Karola Wojtyły, Kraków 2002, s. 309.

${ }^{40}$ Jan Paweł II, adhort. apost. Christifideles laici, 14. 
rocką, gdy przekazuje i umacnia wiarę przez religijne wychowanie i katechizację, popartą przykładem życia swych członków. Rodzina uczestniczy w kapłańskim urzędzie Chrystusa i Kościoła, gdy jako „sanktuarium domowe" troszczy się o chrzest dzieci i przygotowuje je do sakramentów, zwłaszcza Eucharystii. Do kapłańskiej funkcji rodziny należy również modlitwa. W królewskiej władzy Chrystusa rodzina uczestniczy wtedy, gdy w oparciu o czwarte przykazanie Boże rodzice troszczą się o dobro doczesne i wieczne szczęście swoich dzieci. Z czasem ta troska staje się wzajemna i stanowi królewską służbę bliźniemu ${ }^{41}$.

Jeśli chodzi o udział w urzędzie kapłańskim Chrystusa, to naukę soborową przypomniał św. Jan Paweł II w adhortacji Christifideles laici (14). $\mathrm{W}$ jednej z katechez poświęconych temu zagadnieniu, opartej na adhortacji, czytamy, że za sprawą Ducha Świętego świeccy uczestniczą w kapłaństwie Chrystusowym. Chrzest inauguruje obecność i działalność kapłańską Chrystusa w każdym z członków Jego Ciała, podczas gdy Duch Święty napełnia go łaską i pozostawia w jego duszy znamię, obdarzając wierzącego zdolnością żywego uczestnictwa w kulcie oddawanym przez Chrystusa Ojcu w Kościele. Tak Chrystus udziela również świeckim zdolności realizowania w życiu tego kultu, który On sam określił jako „oddawanie czci Ojcu w Duchu i prawdzie” (J 4, 23). „Sobór twierdzi, że w tej właśnie transcendentnej rzeczywistości kapłańskiej misterium Chrystusa świeccy są wezwani do ofiarowania całego swego życia jako duchowej ofiary, współpracując w ten sposób z całym Kościołem w konsekracji świata, dokonywanej nieustannie przez Odkupiciela”. Papież przypomina, że z duchowym kultem wiąże się uczestnictwo świeckich w życiu sakramentalnym: „W sprawowaniu Eucharystii świeccy uczestniczą czynnie, ofiarując samych siebie w zjednoczeniu z Chrystusem Kapłanem i Hostią"42.

Święty Jan Paweł II już w adhortacji apostolskiej Catechesi tradendae (1979) przypomniał o uczestnictwie świeckich w prorockim munus Chrystusa, a zwłaszcza o ich roli w katechizacji parafialnej i misyjnej, w rodzinie, szko-

${ }^{41}$ Por. E. Weron, Apostolstwo małżonków i rodziny w nauczaniu Jana Pawła II, „Collectanea Theologica" 77 (2007) 1, s. 150n.

${ }_{42}$ Jan Paweł II, Uczestnictwo świeckich $w$ kapłaństwie Chrystusowym, katecheza środowa z 15.12.1993, [w:] Jan Paweł II. Świeccy we wspólnocie chrześcijańskiej, dz. cyt., s. 32-34. 
le i środowisku, a także w zrzeszeniach i ośrodkach formacyjnych (66-71) ${ }^{43}$. Odwołując się w jednej z katechez do nauki Soboru i do swej adhortacji Christifideles laici, w następujący sposób syntetycznie ujął naukę na temat udziału świeckich w urzędzie prorockim Chrystusa:

Cechą charakterystyczną powołania świeckich do udziału w urzędzie prorockim Chrystusa, Świadka prawdomównego i wiernego (Ap 1,5), jest ukazywanie, że nie ma sprzeczności pomiędzy naśladowaniem Go a wypełnianiem zadań, których muszą się oni podejmować ze względu na swój charakter „świecki”, oraz że dochowanie wierności Ewangelii służy uzdrawianiu i udoskonalaniu instytucji i struktur doczesnych. [...] Dlatego też Sobór twierdzi, że wierni świeccy są ustanowieni świadkami i zostają wyposażeni „w zmysł wiary i łaskę słowa” (KK 35). Natomiast adhortacja apostolska Christifideles laici dodaje, że są oni uprawnieni i zobowiązani „do tego, by z wiarą przyjęli Ewangelię i głosili ją słowem i czynem, demaskując śmiało i odważnie wszelkie przejawy zła" (14). Wszystko to jest możliwe dzięki temu, że otrzymują oni od Ducha Świętego łaskę wyznawania wiary i znajdowania najlepszego sposobu wyrażania jej i przekazywania wszystkim ${ }^{44}$.

Nie brak w nauczaniu św. Jana Pawła II również wątku królewskości wiernego świeckiego. Nauczanie papieskie koncentruje się na istocie królewskości, dlatego Jan Paweł II w adhortacji Christifideles laici (14) stwierdził:

Z tytułu swej przynależności do Chrystusa, Pana i Króla wszechświata, świeccy uczestniczą także w Jego urzędzie królewskim i są przez Niego wezwani do służenia Królestwu Bożemu i do jego rozszerzania w dziejach. Ludzie ci przeżywają swą chrześcijańską królewskość przede wszystkim poprzez duchową walkę, ażeby pokonać w sobie królestwo grzechu (Rz 6, 12), a następnie poprzez dar z siebie, aby w miłości i sprawiedliwości służyć Jezusowi, który jest obecny we wszystkich braciach, a zwłaszcza najmniejszych (Mt 25, 40). Ale w szczególny sposób świeccy są wezwani do tego, by przywracać stworzeniu całą jego pierwotną wartość. Oni bowiem, poddając stworzenie prawdziwemu dobru człowieka poprzez działalność wspieraną życiem łaski, uczestniczą w sprawowaniu owej władzy, na mocy której zmartwychwstały Jezus przyciagga wszystkie rzeczy do siebie i poddaje je, jak i siebie samego, Ojcu, aby Bóg był wszystkim we wszystkich (J 12, 32; 1 Kor 15, 28 $)^{45}$.

43 Por. S. Mocarski, Uczestnictwo laikatu w katechizacji wedlug adhortacji „Catechesi tradendae”, „Collectanea Theologica” 51 (1981) z. 2, s. 106n.

${ }^{44}$ Jan Paweł II, Udział świeckich w urzędzie prorockim Chrystusa, katecheza środowa z 26.01.1994, [w:] Jan Paweł II. Świeccy we wspólnocie chrześcijańskiej, dz. cyt., s. 36n.

${ }_{45}$ Jan Paweł II, Udziałświeckich w urzędzie królewskim Chrystusa, katecheza środowa z 9.02.1994, [w:] Jan Paweł II. Świeccy we wspólnocie chrześcijańskiej, dz. cyt., s. 40-42. 
W tym kontekście warto zwrócić uwagę na stałe przypominanie przez papieża prawdy, że istnieje zasadnicza różnica między posługami wypływającymi ze święceń a tymi, które nie są z nimi związane ${ }^{46}$. Instrukcja o niektórych kwestiach dotyczących współpracy wiernych świeckich w ministerialnej posłudze kapłanów z 15 sierpnia 1997 roku, podkreślając niezbędność działalności apostolskiej wiernych świeckich dla ewangelizacji, zarówno na płaszczyźnie duchowej, jak też w działalności doczesnej, przypomniała, że dziedzina związana ze świętą posługą kapłańską domaga się od wszystkich, aby ze szczególną gorliwością starali się zachować odrębność zarówno natury i misji posługi kapłańskiej, jak i powołania oraz świeckiej natury laikatu. Współpracować nie znaczy bowiem zastępować ${ }^{47}$.

\section{Inkarnacyjny wymiar duchowości}

Inkarnacyjny wymiar duchowości chrześcijańskiej wynika z faktu wcielenia, przyjścia Syna Bożego na świat. Bruno Forte podkreślając „świeckość” jako wymiar całego Kościoła, zwrócił uwagę na symptomatyczną zmianę nazwy w XIII Schemacie Soboru Watykańskiego II, dotyczącym teologii rzeczywistości ziemskich z De Ecclesia et mundo huius temporis na De Ecclesia in mundo huius temporis. Tym samym w dokumencie, dla którego powstania wielkie zasługi miał biskup krakowski Karol Wojtyła, zrezygnowano z widzenia Kościoła i świata jako dwóch oddzielonych biegunów, stwierdzając istnienie Kościoła obecnego w rzeczywistości świata jako zaczyn i uznając własną, pozytywną wartość tych rzeczywistości ${ }^{48}$. Stąd również w duchowości posoborowej dominuje wysiłek tworzenia duchowości obecności w świecie poprzez staranie, by przezwyciężyć dualizm życia świeckiego i chrześcijańskiego ${ }^{49}$. Wspomniane

46 Por. Jan Paweł II, Apostolstwo i postugi świeckich, katecheza środowa z 2.03.1994, [w:] Jan Paweł II. Świeccy we wspólnocie chrześcijańskiej, dz. cyt., s. 46-48.

47 Por. Instruktion zu einigen Fragen über die Mitarbeit der Laien am Dienst der Priester, [w:] Und dennoch... Die römische Instruktion über die Mitarbeit der Laien am Dienst der Priester. KlarstellungenKritik-Ermutigungen, hg. P. Hünermann, Freiburg 1998, s. 152-154.

48 Por. B. Forte, Laïcat et laïcité, Paris 1986, s. 72 (Collection Maranatha, 11).

49 Por. C. Geffré, Désacralisation et sanctification, „Revue Internationale de Théologie Concilium" 19 (1966), s. 93. 
już Lineamenta synodu na temat świeckich zwołanego przez św. Jana Pawła II w 1987 roku podkreślają szczególnie, że świeccy winni wypełniać doskonale zobowiązania świata w zwyczajnych warunkach swego istnienia, nie oddzielając zjednoczenia z Chrystusem od ich codziennego życia. Winni wzrastać w tym zjednoczeniu, wypełniając własne obowiązki zgodnie z wolą Bożą, co prowadzi do postępu na drodze ku świętości. Dlatego ani troska o rodzinę, ani sprawy doczesne nie mogą być obce ich duchowości. Stąd do istotnych elementów duchowości świeckich zaliczono wezwanie, by szukając Pana, nie uciekać od rzeczywistości ziemskich, ale znajdować i kochać Go przez spełnianie Jego woli w zadaniach każdego dnia. Świeccy winni żyć chrześcijańską nadzieją pośród świata, który przemija, i przez stałe nawracanie się oraz walkę z siłami ciemności winni tę nadzieję przenosić w struktury życia ziemskiego. Podczas aktywności ziemskich i doczesnych winni się coraz bardziej inspirować wiarą i miłością ${ }^{50}$.

Powyższe założenia znalazły się również w adhortacji posynodalnej. Pokazują one pozytywną wizję świata. Taki pełny jego obraz ukazał św. Jan Paweł II w jednej z katechez, stwierdzając, że „świat” może oznaczać środowisko wrogie Bogu i Ewangelii (J 1, 10; 7, 7; 8, 23; 12, 31; 14.16n; 15, 18n; 17, 9; 17, 14nn; 17, 25; 1 J 5, 19). Jednak w samej Ewangelii św. Jana słowo „świat” odnosi się również do całej rzeczywistości ludzkiej, do której skierowane jest posłannictwo zbawienia (J 3, 16n). Zdaniem papieża liczne teksty ewangeliczne potwierdzają postawę łagodności i miłosierdzia, jaką Jezus przyjmował wobec świata jako jego Zbawiciel (J 6, 51; 8, 12; 9, 5; 17, 18; Mt 5, 14). „Dlatego teź świeccy, dalecy od ucieczki od świata, powołani są, by uświęcać go przez swoje zaangażowanie" ${ }^{51}$. Teologicznym fundamentem odpowiedniej duchowości ludzi świeckich jest integralne spojrzenie na prawdy wiary. W tym sensie tajemnica stworzenia znajduje swe dopełnienie w tajemnicy odkupienia. Tę więź podkreślił Jan Paweł II, mówiąc, że „wcielenie i odkupienie nie przekreśla ani

50 Por. Vocation et mission dans l'Église et dans le monde 20 ans après le concile Vatican II. „Lineamenta” pour le Synode des évêques de 1987, Paris 1985, s. 53-56.

${ }^{51}$ Jan Paweł II, Charakter świecki właściwy laikatowi, katecheza środowa z 3.11.1993, [w:] Jan Paweł II. Świeccy we wspólnocie chrześcijańskiej, dz. cyt., s. 13-15. 
nie pomniejsza wartości doczesnych, dzieło Odkupiciela nie sprzeciwia się bowiem dziełu Stworzyciela" ${ }^{2}$.

Nowe, soborowe podejście do świata w kontekście duchowości laikatu wyraził Jan Paweł II słowami:

Świeccy zaś, jako tacy, powołani są i przeznaczeni do oddawania czci Bogu przez używanie rzeczy doczesnych oraz współtworzenie doczesnego postępu społeczeństwa. [...] Zgodnie z tekstem soborowym świecki chrześcijanin, jako taki, obdarzony jest prawdziwym powołaniem, które w przypadku człowieka świeckiego ma swój specyficzny charakter, pozostaje jednak zawsze powołaniem do królestwa Bożego! ${ }^{53}$.

Innym razem święty papież stwierdził:

Jeśli wiara daje nam nową wizję rzeczywistości, to nadzieja dostarcza nowej energii potrzebnej do działania w porząadku doczesnym (Apostolicam actuositatem, 4). W ten sposób świeccy mogą dawać świadectwo, że duchowość oraz apostolat nie uniemożliwiają zaangażowania na rzecz doskonalenia porządku doczesnego. Jednocześnie ukazują oni wielkość celów, do których dążą, oraz ożywiającej ich nadziei, którą pragną podzielić się z innymi. [...] Tak więc ich spojrzenie na dobra zewnętrzne i doczesne przenika wewnętrzna pewność, że należy ich używać, szanując ich przeznaczenie, ale pamiętając zawsze, że są środkiem i drogą do osiągnięcia doskonałości życia wiecznego. Wszystko to dokonuje się w mocy miłości, którą Duch Święty rozlewa w duszy (Rz 5, 5), by mogła ona uczestniczyć w życiu Bożym już na ziemi ${ }^{54}$.

Ten wymiar bycia danym i zadanym, tkwiący w rzeczywistości doczesnej, dotyczy nie tylko natury, ale również szeroko pojętej kultury. Sobór podkreślił potrzebę należytej wolności kultury przy zachowaniu praw osoby ludzkiej i wspólnoty w granicach dobra wspólnego. Przypomniał o prawie wszystkich do korzystania z dobrodziejstw kultury oraz o prawie i obowiązku tworzenia kultury prawdziwie ludzkiej, służącej dobru wspólnemu ${ }^{55}$. To właśnie ludzie świeccy winni przepajać kulturę wartościami moralnymi (KK 36) ${ }^{56}$. Jan Paweł II nauczał, że pomoc Kościoła w należytym kształ-

${ }^{52}$ Jan Paweł II, Zadania świeckich w porzadku doczesnym, katecheza środowa z 13.04.1994, [w:] Jan Paweł II. Świeccy we wspólnocie chrześcijańskiej, dz. cyt., s. 64.

53 Jan Paweł II, Charakter świecki właściwy laikatowi, katecheza środowa z 3.11.1993, [w:] Jan Paweł II. Świeccy we wspólnocie chrześcijańskiej, dz. cyt., s. 12n.

54 Jan Paweł II, Duchowość świeckich, katecheza środowa z 1.12.1993, [w:] Jan Paweł II. Świeccy we wspólnocie chrześcijańskiej, dz. cyt., s. 30.

55 Sobór Watykański II, konst. Gaudium et spes [dalej: KDK], 59n.

56 Por. J. Dyduch, Obowiązki i prawa wiernych świeckich w prawodawstwie soborowym, Kraków 1985, s. 196. 
towaniu całego porządku doczesnego i kierowaniu go przez Chrystusa do Boga zawiera szczególną odpowiedzialność i powołanie świeckich do promocji osoby ludzkiej. Świeccy powołani są do angażowania się w życie polityczne, do wspierania wysiłku społeczeństw zmierzającego do ustanowienia pokoju w świecie i do zaangażowania się w rozwój gospodarczo-społeczny. Świeccy mają też wnosić wkład w ludzką kulturę poprzez inspirowane wiarą rozwijanie różnych dziedzin wiedzy, twórczości artystycznej, myśli filozoficznej czy badań historycznych ${ }^{57}$. Istotne jest tutaj wzajemne przenikanie się Ewangelii i kultury z obopólnym pożytkiem ${ }^{58}$.

W nauczaniu Jana Pawła II szczególne znaczenie ma duchowość pracy ludzkiej. Praca w aspekcie religijnym jest pierwotnym wyrazem „charakteru świeckiego” laikatu, który w przeważającej części składa się z pracowników i w pracy może odnaleźć drogę prowadzącą do świętości. Praca stanowi drogę do świętości, bo stwarza okazję do: doskonalenia samego siebie, pomagania współobywatelom, postępu całej społeczności i stworzenia, naśladowania Chrystusa przez praktykowanie czynnej miłości. Trud pracy wymaga cnoty odwagi i cierpliwości, co stanowi jej ascetyczny wyraz. Trud ten i związane z nim cierpienie dzięki uczestnictwu w odkupieńczej ofierze Chrystusa przynosi nadprzyrodzone owoce całemu rodzajowi ludzkiemu ${ }^{59}$. Zwłaszcza duchowość pracy ludzkiej zawarta w piątej części encykliki świętego papieża Laborem exercens z 1981 roku ukazuje pracę jako uczestnictwo w dziele stwórczym Boga i w misterium paschalnym Chrystusa. Przez pracę człowiek może się doskonalić i uświęcać, może coraz bardziej stawać się człowiekiem, a także łączyć się z ludźmi i służyć im, praktykując szczerą miłośćco.

Drugim wymiarem szczególnej odpowiedzialności ludzi świeckich za świat jest polityka. Dla Jana Pawła II polityka oznacza ludzką, czyli świadomą i wolną działalność, nacechowaną roztropnością i zmierzającą do wspólnego do-

57 Por. Jan Paweł II, Zadania świeckich w porządku doczesnym, katecheza środowa z 13.04.1994, [w:] Jan Pawet II. Świeccy we wspólnocie chrześcijańskiej, dz. cyt., s. 65-67.

58 Por. A. Bławat, Jan Paweł II o stosunku Kościoła katolickiego do kultury, „Collectanea Theologica” 57 (1987) z. 3, s. 106.

${ }_{59}$ Por. Jan Paweł II, Świat pracy w Kościele, katecheza środowa z 20.04.1994, [w:] Jan Paweł II. Świeccy we wspólnocie chrześcijańskiej, dz. cyt., s. 69-72.

${ }_{60}$ Por. M. Dąbrowska, Duchowość pracy ludzkiej w świetle encykliki „Laborem exercens”, „Collectanea Theologica” 53 (1983) z. 1, s. 128-130. 
bra. Jest działalnością mocno osadzoną w miłości i solidarności społecznej. Tak rozumiana polityka jest obowiązkiem każdego człowieka, a szczególnie wiernych świeckich. Jest to dążenie do wspólnego dobra, zakładające obronę i promocję sprawiedliwości i uwzględniające autonomię rzeczywistości ziemskich. Taka działalność winna płynąć z ducha służby i być świadectwem wartości ludzkich i ewangelicznych, zwłaszcza solidarności. Dzięki temu winna zmierzać ku pokojowi ${ }^{61}$. Papież przypominał, że „świeccy chrześcijanie powinni dać przykład uczciwej polityki, która nie szuka osobistych korzyści ani nie służy interesom grup i partii przy pomocy niegodziwych środków, prowadzących w efekcie do upadku najbardziej szlachetnych i świętych ideałów"62. Wynika z tego, że w ujęciu świętego papieża praca, polityka i wszelkie zaangażowanie się człowieka świeckiego w kształtowanie doczesności w duchu Ewangelii mogą być drogą do świętości.

\section{Powszechne powołanie do świętości}

Od pierwszych wieków Kościoła przekonanie wiernych poświadczone przez autorytet dostarczało głównych modeli świętości. Najpierw było to heroiczne świadczenie o Chrystusie w świecie zarówno słowem, jak i krwią. Nawet ojcowie Kościoła, wywyższający życie monastyczne, wiedzieli, że gorliwy świecki może przewyższyć świętością członków innych stanów, gdyż o jej osiągnięciu świadczy stopień miłości. W średniowiecznej wizji duchowości monastycznej wzorami świętości byli głównie zakonnicy, papieże i biskupi. W XIII wieku pojawiło się pojęcie „stanu świętości”, związane z życiem zakonnym, przy czym świeccy mogli się do świętości zbliżyć przez trzecie zakony. Dekret Gracjana mówiący, że „duo sunt genera christianorum”, wyraża panujące przez długie wieki przekonanie o trudności osiągania świętości w świecie. W oświeceniu nastąpiła redukcja samej idei świętości, co uwidoczniło się w niewielkiej liczbie kanonizacji. Zasadniczo droga do świętości

${ }^{61}$ Por. K. Tyszka, Polityka według Jana Pawła II, „Collectanea Theologica” 76 (2006) z. 4, S. $181-183$.

${ }^{62}$ Jan Paweł II, Zadania świeckich w porzadku doczesnym, katecheza środowa z 13.04.1994, [w:] Jan Paweł II. Świeccy we wspólnocie chrześcijańskiej, dz. cyt., s. 66. 
miała czerwony kolor męczeństwa oraz czarny życia kapłańskiego i zakonnego. Choć przed Franciszkiem Salezym napisano wiele wprowadzeń do życia pobożnego dla wszystkich wiernych, to jednak dopiero on z całą mocą zaczął postulować dochodzenie do doskonałości w każdym stanie i zawodzie. Znamienna jest ewolucja, która pokazuje, że w latach 1801-1960 świeccy stanowili 12 proc. kanonizowanych, podczas gdy w latach 1960-1983 już 33 proc., z czego dwie trzecie stanowili męczennicy. Już Pius XI w encyklice Rerum omnium z 1923 roku pisał, że świętość nie jest darem nadzwyczajnym, zarezerwowanym dla nielicznych, ale stanowi wspólną powinność i cel wszystkich. Stało się to wyraźne po Soborze Watykańskim II, który podkreślił, że świętość nie jest jedynie domeną „,areny, klasztoru czy zakrystii”, ale wspólnym powołaniem wszystkich wiernych (KK 40) ${ }^{63}$.

Wielkie zasługi w ukazywaniu wiernym świeckim drogi do świętości ma święty Jan Paweł II. Wspomniane już Lineamenta synodu biskupów przypominając, że duchowość stanowi duszę apostolatu, a płodność apostolska świeckich zależy od ich zjednoczenia z Chrystusem, definiują duchowość jako życie według Ducha, do którego wezwany jest każdy chrześcijanin. Nawiązując do nauki soborowej o powszechnym powołaniu do świętości i różnorodności duchowości w zależności od stanów życia i posług (KK 41), biskupi uznali za konieczne, by świeccy żyli specyficzną, właściwą im duchowością. Duchowość ta, jak każda duchowość chrześcijańska, winna czerpać ze wspólnych źródeł słowa Bożego, sakramentów, modlitwy i życia cnotą miłości, które inspirują do życia ewangelicznego i wypełniania obowiązków rodzinnych, zawodowych, społecznych, politycznych i kulturalnych ${ }^{64}$.

Szczególnie za pontyfikatu Jana Pawła II wiele osób świeckich dostąpiło wyniesienia na ołtarze. Mimo to słyszy się głosy, że wciąż za mało świeckich zostaje beatyfikowanych i kanonizowanych. $Z$ danych podanych przez Henryka Misztala wynika, że około 15 proc. spraw wniesionych do Kongregacji Spraw Kanonizacyjnych dotyczy ludzi świeckich. Nie wynika to jednak z mniejszej liczby świętych ludzi pośród laikatu czy wręcz z większych trudności osiąg-

${ }_{63}$ Por. P. Langeron, Les instituts séculiers. Une vocation pour le nouveau millénaire, Paris 2003, s. 52-54; por. G. Thils, Les laïcs et l'enjeu..., dz. cyt., s. 90-92.

${ }^{64}$ Por. Vocation et mission dans l'Église et dans le monde 20 ans après le concile Vatican II. „Lineamenta” pour le Synode des évêques de 1987, Paris 1985, s. 53-56. 
nięcia doskonałości w tym stanie życia. Nie brak kandydatów, a raczej trudności organizacyjne są tego powodem. Zakony i diecezje dysponują odpowiednio przygotowanymi ludźmi i większymi możliwościami materialnymi, by dokumentować życie kandydatów na ołtarze i promować ich sylwetki. Z drugiej strony dotąd wyniesieni na ołtarze świeccy zachwycają nas różnorodnością form naśladowania Chrystusa, które mniej niż w wypadku duchownych i zakonników podlegają schematom, wzorom i regułom zachowań $^{65}$. Znakiem czasu jest wielkie oddziaływanie świętych na wiernych, co stanowi wyraz pragnienia pogłębionego życia duchowego. Wielu współczesnych świętych wciela wartości ludzkie w ideał świętości, przez co są bliscy sposobem życia dzisiejszym wiernym. Nowe ruchy i wspólnoty czynią ze świętości swój program życia, odkrywając, że powołanie do niej jest nie tyle wymaganiem, ile znakiem bezgranicznej miłości Boga do człowieka ${ }^{66}$.

Naukę na temat powszechnego powołania do świętości Jan Paweł II zwięźle wyraził podczas jednej z katechez:

Kościół jest święty i wszyscy jego członkowie powołani są do świętości. Świeccy uczestniczą w świętości Kościoła jako pełnoprawni członkowie wspólnoty chrześcijańskiej. To uczestnictwo w świętości Kościoła, które moglibyśmy nazwać ontologicznym, również w przypadku świeckich znajduje swój wyraz w etycznym i osobistym dążeniu do świętości. Ze względu na tę zdolność i powołanie do świętości wszyscy członkowie Kościoła są równi (Ga 3, 28). Stopień osobistej świętości nie zależy od pozycji zajmowanej w społeczeństwie ani w Kościele, lecz jedynie od tego, w jakiej mierze człowiek żyje miłością ${ }^{67}$.

Stąd w osiąganiu świętości dla wszystkich ochrzczonych miarodajne jest zbliżanie się do Boga. Jan Paweł II nauczał, że powołanie świeckich pociąga za sobą ich uczestnictwo w życiu Kościoła i w konsekwencji ścisłą więź z życiem Chrystusa. Jest to Boży dar, z którym jednocześnie wiąże się określone zadanie ${ }^{68}$. Ta więź z Chrystusem dotyczy zarówno tajemnicy Jego wcielenia, jak i krzyża. Święty papież wyraził to słowami: „W świetle wia-

${ }_{65}$ Por. H. Misztal, Doskonali w miłości. Świeccy święci i błogosławieni, Lublin 1992, s. 410.

66 Por. C. García, Espiritualidad..., dz. cyt., s. 127n.

${ }^{67}$ Jan Paweł II, Powołanie świeckich do świętości, katecheza środowa z 24.11.1993, [w:] Jan Paweł II. Świeccy we wspólnocie chrześcijańskiej, dz. cyt., s. 22.

68 Por. Jan Paweł II, Świeccy wobec tajemnicy Chrystusa, katecheza środowa z 10.11.1993, [w:] Jan Paweł II. Świeccy we wspólnocie chrześcijańskiej, dz. cyt., s. 18n. 
ry świeccy żyjący zgodnie z logiką wcielenia, które się dokonało dla naszego odkupienia, uczestniczą również w tajemnicy zbawczego Krzyża. W życiu Chrystusa wcielenie i odkupienie stanowią jedną tajemnicę miłości"69. Konieczne tu jest owocne życie sakramentalne. Obszernie na ten temat mówił Jan Paweł II podczas jednej z katechez, podkreślając wagę chrztu, bierzmowania, Eucharystii, sakramentu pojednania i małżeństwa ${ }^{70}$.

Inkarnacyjny wymiar duchowości laikatu musi brać pod uwagę w dążeniu do świętości wypełnianie obowiązków stanu. Jednak Jan Paweł II podkreślał również konieczność znajdywania czasu bezpośrednio na modlitwę:

Niewątpliwie, kiedy staramy się działać zgodnie z wolą Bożą, czynimy rzeczy miłe Panu i jest to już forma modlitwy. Tak więc nawet najprostsze czyny stają się wyrazem czci oddawanej Bogu i są Mu miłe. Jest jednak również prawdą, że to nie wystarcza: potrzebne są specjalne momenty przeznaczone wyłącznie na modlitwę, zgodnie z przykładem pozostawionym przez Jezusa, który nawet w okresie najbardziej intensywnej działalności mesjańskiej znajdował czas na modlitwę (Łk 5, 16). Odnosi się to do wszystkich, a więc i do świeckich. Różnorodne mogą być formy tego rodzaju „przerw” na modlitwę: ale w każdym przypadku liczy się zasada, że modlitwa jest dla wszystkich niezbędna zarówno w życiu osobistym, jak i w apostolacie. Jednak dzięki intensywnemu życiu modlitwy świeccy mogą znaleźć natchnienie, energię, odwagę w obliczu trudności i przeszkód, wytrwałość i umiejętność podejmowania inicjatyw i odzyskiwania sił71.

\section{Zakończenie}

Koncepcja Kościoła jako societas perfecta i societas inaequalis podkreślała aspekt instytucjonalny i wprowadzała brak równowagi między funkcją hierarchiczną a laikatem we wspólnocie wierzących. W tej sklerykalizowanej koncepcji za bardzo podkreślano strukturalne i funkcjonalne różnice pomiędzy pasterzami a wiernymi, Ecclesia docens i Ecclesia discens, autorytetem i posłuszeństwem. Dla wielu Kościół był wspólnotą księży posiada-

${ }_{69}$ Jan Paweł II, Świeccy wobec tajemnicy Chrystusa, katecheza środowa z 10.11.1993, [w:] Jan Pawet II. Świeccy we wspólnocie chrześcijańskiej, dz. cyt., s. 20.

70 Por. Jan Paweł II, Promocja laikatu chrześcijańskiego w perspektywie nowych czasów, katecheza środowa z 21.09.1994, [w:] Jan Paweł II. Świeccy we wspólnocie chrześcijańskiej, dz. cyt., s. 132n.

${ }^{71}$ Jan Paweł II, Duchowość świeckich, katecheza środowa z 1.12.1993, [w:] Jan Paweł II. Świeccy we wspólnocie chrześcijańskiej, dz. cyt., s. 28n. 
jących autorytet hierarchiczny i władzę sakramentalną. Poniżej był lud Boży. Kościół zdawał się instytucją klerykalną. Sobór Watykański II (19621965), przede wszystkim w konstytucji Lumen gentium, odnowił oblicze Kościoła ${ }^{72}$. Rozwój teologiczny dotyczący laikatu od soboru krążył wokół godności chrzcielnej świeckiego w Kościele i świecie, uczestnictwa w potrójnym munus Chrystusa, działania Ducha Świętego w historii, rewaloryzacji charyzmatów, funkcji i posług świeckich. Starano się coraz lepiej zrozumieć specyficzne powołanie świeckiego, jego świeckie znamię, jego rolę wewnątrz relacji Kościoła i świata. Sformułowano wreszcie teologicznie koncepcję Kościoła-komunii i Kościoła-misji, w której ramach można bardziej harmonijnie ukazać powołanie i misję człowieka świeckiego ${ }^{73}$. Jak to wynika z powyższego tekstu, wiele zasług w tej dziedzinie należy przypisać świętemu papieżowi Janowi Pawłowi II.

72 Por. A. Antón, Principios Fundamentales..., dz. cyt., s. 112; P. Langeron, Les instituts séculiers..., dz. cyt., s. 61-63.

73 Por. C. García, Espiritualidad..., dz. cyt., s. 169. 


\section{Summary}

\section{Saint John Paul II about spirituality of lay people}

The author of this article shows input of saint John Paul II in the understanding of spirituality of lay people. The article proves that the papal teaching about the laity is a continuation of the teaching of The Second Vatican Council and also brings some new elements. The particular attention paid to the communion dimension of the Church should be emphasized. The author also discusses the participation of lay people in the threefold office of the Christ, incarnational dimension of the lay spirituality and the question of the common call to sanctity.

Keywords: spirituality, laity, John Paul II

\section{Święty Jan Paweł II o duchowości laikatu}

Autor artykułu ukazuje wkład św. Jana Pawła II w rozumienie duchowości ludzi świeckich. Udowadnia, że nauczanie papieża na temat laikatu stanowi kontynuację nauczania Soboru Watykańskiego II, ale wnosi też nowe akcenty. Na podkreślenie zasługuje szczególny akcent położony na komunijny wymiar Kościoła. Autor omawia też udział świeckich w potrójnym urzędzie Chrystusa, inkarnacyjny wymiar duchowości laikatu i kwestię powszechnego powołania do świętości.

Słowa kluczowe: duchowość, laikat, Jan Paweł II

\section{Bibliografia}

Antón A., Principios Fundamentales para una teología del Laicado en la Eclesiología del Vaticano II, „Gregorianum” 68 (1987) 1-2, s. 103-155.

Bławat A., Jan Paweł II o stosunku Kościoła katolickiego do kultury, „Collectanea Theologica” 57 (1987) z. 3, s. 105-113.

Bławat A., Watykański dokument o współdziałaniu mężczyzny i kobiety, „Collectanea Theologica" 76 (2006) z. 2, s. 189-196.

Congar Y., Laïc et Laïcat, [w:] Dictionnaire de spiritualité, t. 9, Paris 1976, k. 79-108.

Dąbrowska M., Duchowość pracy ludzkiej w świetle encykliki „Laborem exercens”, „Collectanea Theologica" 53 (1983) z. 1, s. 126-130.

Dupuis J., Lay people in Church and world. The contribution of recent literature to a synodal theme, „Gregorianum” 68 (1987) 1-2, s. 347-390.

Dyduch J., Obowiązki i prawa wiernych świeckich w prawodawstwie soborowym, Kraków 1985.

Forte B., Laïcat et laïcité, Paris 1986 (Collection Maranatha, 11). 
García C., Espiritualidad de los laicos, Burgos 2004.

Geffré C., Désacralisation et Sanctification, „,Revue Internationale de Théologie Concilium” 19 (1966), s. 93-108.

Goldie R., Świeccy, laikat, świeckość, tłum. S. Wawrzkowicz, Warszawa-Poznań 1991.

Homélie du pape Jean-Paul II pour la béatification de Luigi et Maria Beltrame Quattrocchi, „Carmel” 12 (2001) 102, s. 57-61.

Hünermann P., Zum kirchenpolitischen Hintergrund und zur Bedeutung der Instruktion, [w:] Und dennoch... Die römische Instruktion über die Mitarbeit der Laien am Dienst der Priester. Klarstellungen-Kritik-Ermutigungen, hg. P. Hünermann, Freiburg 1998, s. 9-28.

Instruktion zu einigen Fragen über die Mitarbeit der Laien am Dienst der Priester, [w:] Und dennoch... Die römische Instruktion über die Mitarbeit der Laien am Dienst der Priester. KlarstellungenKritik-Ermutigungen, hg. P. Hünermann, Freiburg 1998, s. 152-164.

Jacobs A., Les laïcs, membres du peuple de Dieu, à travers le Code de droit canonique, „Revue Théologique de Louvain" (1987) 1, s. 30-47.

Jan Paweł II, Adhortacja apostolska Christifideles laici.

Jan Paweł II, Adhortacja apostolska Familiaris consortio.

Jan Paweł II, Apostolstwo i posługi świeckich, katecheza środowa z 2.03.1994, [w:] Jan Paweł II. Świeccy we wspólnocie chrześcijańskiej, red. E. Weron, Poznań 1997, s. 46-48.

Jan Paweł II, Apostolstwo małżonków i rodziców, katecheza środowa z 3.08.1994, [w:] Jan Paweł II. Świeccy we wspólnocie chrześcijańskiej, red. E. Weron, Poznań 1997, s. 108-111. Jan Paweł II, Charakter świecki właściwy laikatowi, katecheza środowa z 3.11.1993, [w:] Jan Paweł II. Świeccy we wspólnocie chrześcijańskiej, red. E. Weron, Poznań 1997, s. 13-15.

Jan Paweł II, Duchowość świeckich, katecheza środowa z 1.12.1993, [w:] Jan Paweł II. Świeccy we wspólnocie chrześcijańskiej, red. E. Weron, Poznań 1997, s. 30.

Jan Paweł II, List apostolski Mulieris dignitatem.

Jan Paweł II, List do rodzin z 2 lutego 1994 roku.

Jan Paweł II, Powołanie świeckich do świętości, katecheza środowa z 24.11.1993, [w:] Jan Paweł II. Świeccy we wspólnocie chrześcijańskiej, red. E. Weron, Poznań 1997, s. 22.

Jan Paweł II, Promocja laikatu chrześcijańskiego w perspektywie nowych czasów, katecheza środowa z 21.09.1994, [w:] Jan Pawet II. Świeccy we wspólnocie chrześcijańskiej, red. E. Weron, Poznań 1997, s. 132n.

Jan Paweł II, Świat pracy w Kościele, katecheza środowa z 20.04.1994, [w:] Jan Paweł II. Świeccy we wspólnocie chrześcijańskiej, red. E. Weron, Poznań 1997, s. 69-72.

Jan Paweł II, Świeccy we wspólnocie chrześcijańskiej, red. E. Weron, Poznań 1997.

Jan Paweł II, Świeccy wobec tajemnicy Chrystusa, katecheza środowa z 10.11.1993, [w:] Jan Paweł II. Świeccy we wspólnocie chrześcijańskiej, red. E. Weron, Poznań 1997, s. 20.

Jan Paweł II, Uczestnictwo świeckich w kapłaństwie Chrystusowym, katecheza środowa z 15.12.1993, [w:] Jan Paweł II. Świeccy we wspólnocie chrześcijańskiej, red. E. Weron, Poznań 1997, s. 32-34.

Jan Paweł II, Udział świeckich w urzędzie królewskim Chrystusa, katecheza środowa z 9.02.1994, [w:] Jan Paweł II. Świeccy we wspólnocie chrześcijańskiej, red. E. Weron, Poznań 1997, s. 40-42. 
Jan Paweł II, Udział świeckich w urzędzie prorockim Chrystusa, katecheza środowa z 21.01.1994, [w:] Jan Paweł II. Świeccy we wspólnocie chrześcijańskiej, red. E. Weron, Poznań 1997, s. 36-39.

Jan Paweł II, Zadania świeckich w porzadku doczesnym, katecheza środowa z 13.04.1994, [w:] Jan Paweł II. Świeccy we wspólnocie chrześcijańskiej, red. E. Weron, Poznań 1997, s. 64.

Kasper W., Berufung und Sendung des Laien in Kirche und Welt. Geschichtliche und systematische Perspektiven, „Stimmen der Zeit” 205 (1987), s. 579-593.

Katechizm Kościoła katolickiego, Poznań 1994.

Książek Z., Świeccy w posłudze biskupiej kardynała Karola Wojtyły, Kraków 2002.

Langeron P., Les instituts séculiers. Une vocation pour le nouveau millénaire, Paris 2003.

Lizotte A., La relation homme - famme comme signe de l'Amour divin, „Carmel” 12 (2001) 102, s. 17-19.

Misztal H., Doskonali w miłości. Świeccy święci i błogosławieni, Lublin 1992.

Mocarski S., Uczestnictwo laikatu w katechizacji według adhortacji „Catechesi tradendae”, "Collectanea Theologica” 51 (1981) z. 2, s. 135-138.

Nagy S., Świeccy w komunijnej wspólnocie Kościoła, „Ateneum Kapłańskie” 114 (1990) z. 3, s. 377-3879.

Reroń T., Rodzina, [w:] Leksykon duchowości katolickiej, red. M. Chmielewski, Lublin 2002, s. 753-756.

Schillebeeckx E., La définition typologique du laïc chrétien selon Vatican II, [w:] L'Église de Vatican II. Commentaires, t. III, Paris 1966.

Schotte J., „Christifideles laici” - prezentacja dokumentu, „Ateneum Kapłańskie” 114 (1990) z. 3, s. 359-364.

Słomka W., Cywilizacja miłości według Jana Pawła II „Listu do Rodzin”, , Roczniki Teologiczne” 42 (1995) z. 5, s. 27-38.

Thils G., Les laïcs et l'enjeu des temps „post-modernes”, Louvain-la-Neuve 1988.

Tyszka K., Polityka wedlugJana Pawła II, ,, Collectanea Theologica” 76 (2006) z. 4,s. 179-185.

Vocation et mission dans l'Église et dansle monde 20 ans après le concile Vatican II. „Lineamenta” pour le Synode des évêques de 1987, Paris 1985, s. 53-56.

Warzecha J., Papieska teologia małzeństwa, „Collectanea Theologica” 51 (1981) z. 3, s. 131-137.

Weron E., Apostolstwo małżonków i rodziny w nauczaniu Jana Pawła II, „Collectanea Theologica" 77 (2007) z. 1, s. 147-155.

Weron E., Budzenie olbrzyma, Poznań 1995.

Weron E., Laikat w nowym katechizmie Kościoła, „Collectanea Theologica” 65 (1995) z. 4, s. 135-139.

Weron E., Teologia życia wewnętrznego ludzi świeckich, Poznań-Warszawa 1980. 